\title{
CHARACTERISTICS OF CLASSROOM INTERACTION OF ENGLISH LANGUAGE TEACHERS IN INDONESIA AND MALAYSIA
}

\author{
Akhyar Rido \\ Faculty of Arts and Education, Universitas Teknokrat Indonesia \\ Email:akhyar_rido@teknokrat.ac.id \\ Fatimah Mulya Sari \\ Faculty of Arts and Education, Universitas Teknokrat Indonesia \\ Email:fatimah@teknokrat.ac.id \\ DOI: http://dx.doi.org/10.26858/ijole.v2i1.5246
}

\begin{abstract}
This study investigated characteristics of classroom interaction of English language teachers in Indonesia and Malaysia, focusing on language accuracy and classroom discourse. A qualitative method was employed in this study while the data was gathered through observation of six teaching sessions of English language teaching in secondary schools, involving three selected Indonesian teachers and three selected Malaysian teachers. The findings reveal that all teachers performed two characteristics of classroom interaction namely language accuracy and classroom discourse. In teachers' language accuracy, the Indonesian and Malaysian teachers delivered pronunciation, vocabulary, instructions, questions, explanations, eliciting information, use of L1, and correction of language errors. They also applied monologue, dialogue, restructure discourse, fill gaps for students lack of language, use of L1/L2 both teachers and students, accepting incomplete answers from students, and accepting one word answers. These categories improved the quality of teacherstudent and student-student interaction. Therefore, the findings might be implemented more widely to enrich both Indonesian and Malaysian English language teachers.
\end{abstract}

Keywords: characteristics of classroom interaction, English language teachers, teachers' language accuracy, classroom discourse

\section{INTRODUCTION}

The characteristics of teachers and teaching and learning are closely interwoven (Kuijpers, Houtveen, \& Wubbels 2010; Richards \& Farrell, 2005). In the classrooms, teachers do not only act as a guide, facilitator, and counsellor (Brown, 2000; Ibrahim, Haniem, Nambiar, 2013; Richards \& Rodgers, 2001; Rido, Ibrahim, Nambiar, 2016), but also give suggestions and ask questions as they do the activities (Rido, 2017). They model the target language, control the direction and pace of learning, and monitor as well as correct learners' performance (Boor, Aman, Mustaffa, Seong, 2010; Rido, Ibrahim, Nambiar, 2014, 2015; Rido, 2010; Walsh, 2011).
Studies have shown that teachers roles define the characteristics of their classroom interaction (Dagarin, 2004; Hall \& Walsh, 2002; Richards \& Schmidt, 2010; Rido, 2017; Rido, Ibrahim, Nambiar, 2014, 2015). Interaction is a salient pattern where both teachers and students come into contact to share information and knowledge, especially in language classrooms. It raises the effectiveness of language teaching-learning process as there is the involvement of two-way interaction and an active participation between teachers and students in the classroom activities (Li \& Arshad, 2015; Rido et.al., 2017; Rido, Ibrahim, Nambiar, 2016; Rido, 2017; Tsui, 2001). However, there are still growing concerns on the competence of English language teachers, 
especially in Indonesia and Malaysia. A number of studies have found that the teachers' lack of English language competence is a major problem in English language classrooms. These teachers could not promote effective interaction; and, as a consequence, the students failed to understand the lesson (Boor, Aman, Mustaffa, Seong, 2010; Mattarima \& Hamdan, 2011; Marcellino, 2009; Rido, 2018; Zulfikar, 2009; Lie 2007).

The concern on the success of teaching process leads a study to explore and identify the characteristics of classroom interaction. As the whole ecosystem is changing, teachers are required to cope with the latest trends and give the best learning experience to their students (Di Grapello, 2013; Lie, 2007; Suharti, 2013). Thus, this study is aimed at investigating characteristics of interaction used by the teachers in Indonesia and Malaysia, focusing on their language accuracy and classroom discourse. The discussion is based on the information gauged from classroom observation.

\section{RESEARCH METHOD}

The study was conducted at six secondary schools in Indonesia and Malaysia. The participants were three Indonesian teachers (T1, T2, T3) and three Malaysian teachers (T4, T5, T6). Data for this study were collected through observation and video-recording. The observation was carried out by idenfying all potentially relevant occurances of interactions' characteristics of the teachers. The nonparticipant observation was suitable since the observer remained inconspicuous so that the characteristics of classroom intearction were not affected (Angrosino \& Rosenberg, 2013). Video-recordings were also allowed during the observations in the six English language classes. Video-recordings are a relatively straightforward means of recording interaction in the classroom and have the added advantage of providing a visual representation of what is happening (Howard, 2010; Walsh, 2011;
Wong \& Waring, 2010). 80 minutes from each session was recorded on video. The data from observation were coded based on two characteristics - teachers' language accuracy and classroom discourse. In this current study, teachers' language accuracy comprises some sub-characteristics which cover pronunciation, vocabulary, instructions, questions, explanations, eliciting information, use of L1 (mother tongue), and correction of language error. Meanwhile, classroom discourse consists of monologue, dialogue, restructure discourse, fill gaps for students lack of language, use of L1/L2 (for both teacher and students), accepting incomplete answers from students, and accepting one word answers. Recurring characteristics of classroom interaction exhibited by the teachers in the classroom activities were identified and categorized through reading and re-reading the data. After that, similar characteristics might be developed and the emergent themes were presented.

\section{FINDINGS}

After analyzing the data, the results show multitude views of characteristics of classroom interaction between Indonesian and Malaysian teachers which, in some extent, varies. In this currect study, the characteristics are divided into two-teachers' language accuracy and classroom discourse, with some subcharacteristics in each part. To capture the essence of the findings, extracts will be represented, where necessary.

\section{Teachers' Language Accuracy}

The findings related to the teachers' language accuracy have several subcharacteristics. Those sub-characteristics are pronunciation, vocabulary, instructions, questions, explanations, eliciting information, use of L1, and correction of language error. In Indonesia, the teachers frequently used bahasa Indonesia in delivering the material while the Malaysian teachers used English as the 
medium of instruction during the lessons. In addition, the three Malaysian teachers produced clear articulation of words and used English during the lessons. They asked questions, gave direction/instruction and explanation, elicited information, and corrected language errors. They also showed minor grammatical problems during teaching.

The first view points at giving instruction. Classroom instruction was conducted exclusively in the target language. The teachers gave instructions to the students when they explained the material and asked the students to read the text and dialogue. Teacher's instructions is needed as the students need guidance in their learning process. Providing instructions can help the learners in attaining the aim of the learning, guiding the students, managing their activities, and directing their learning (Lomax \& Ferguson, 2002; Jones, 2007). The following extracts show how the teachers gave instruction during the lesson.

The extract of T1's:

Please look at your paper.

Look at your photocopy, ya [showing her

$T$ handout], ok. [the teacher shows the paper in front of the class and the students pay attention to the content].

The extract of T2's:

T ...... Okfirst, I would like you to divide into two groups.

S Two groups bu? Iya two groups. Ok. Danu, would you like to move here? Move here. Ya. And then

$T \quad$ Anas would you like to move here. Panji, move there. Indra and Febri here. Tamim move here.

S Move here?

Ya move here. [and then the teacher just use her finger to move the rest of students]

$T \quad$ [the students one by one move based on the position of teacher's finger] Ok ya. (.) here.

The extract of T3's:
But know, telephone is not only for communicating ya, sekarang line telfon sudah bisa di pake untuk mail, internet, browsing a book. That the extension for the sophisticated version of telephone. Ya sebagai anak teknologi kan

$T$ harus tau tentang itu. Ok eeee now, take a look at this. [seeing her paper] It is about telephone.

Maybe I will ask one of you to read. Ahmad. Can you read the first paragraph? [approaching the student]

The others please listen ya.

The extract of T4's:

Alright, So, are you fine? (.) Okay? Wonderful? What happen to you ( ) still holding your back like that? Still sleepy? Still sleepy? (.) Put it down! Put it down! You don't have to hold your bag. Alright, so, before we start our class today I just want to have one student to volunteer to come in front as usual (.) Anybody want to volunteer before I call name? (.) Anyone? (Vanterap) please come here. Come here. He is looking straight to me. Alright come here. Good come here [students clap and make some noise] Others are facing down you see looking down, but you are the one who is looking straight to me when I ask to volunteer. Come on. Come here. (.) Don't worry, don't be so afraid. You are doing this all the time. Alright (.) ehhmm...ehhhmm... do as handsome as possible [students laugh] Okay, yesterday we had a meeting ah sorry we had an event in our school. What was it? Debate

The extract of T5's:

Okay go to chapter one (.) any volunteer?

T Any volunteer?

Okay you give me a number (.)

give me a number (.)

The extract of T6's:

Okay now today's lesson is also about our local customs but today you are going to make a list of tips that you are going to give to your friend (.) imagine you have friend (.) someone in UK or 
in Japan or in Korea and your friend is planning to visit our/ country (.) and this is his or her first time/ visit (.) so you want to help your friend so that he or she is prepares before she they come (.) here alright (.) s for today's activity alright you have to rearrange the words okay so that (.) rearrange the words into their correct orders and it will give you tips that you are going to share with your/ friends (.) is that clear?

Another point, teacher's question is one manifestation of teacher talk and a fundamental discursive tool in the communicative exchanges that serve a natural interaction in the classroom, check comprehension and attention (Hall, 2011; Farahian \& Rezaee, 2012), and build understanding of complex concepts (Long et al., 1984, cited in Tuan and Nhu, 2010; McCormick and Donato, 2000; Fisher \& Frey, 2009). In this part, the teachers play the part of ringmaster; they ask questions. Most of which are yes/no questions and display questions that require the students to provide the answers which the teacher already knows. In questioning, the teachers employed general practice technique including chorus repetition, drills, and controlled oral-based reading and writing tasks. It is easier for the students to answer questions than to initiate a conversation since the questions given were mostly about the lesson material, general knowledge, and up-to-date topics. In Indonesian teachers, most of display questions and yes-no questions were asked. The following extract shows how the teachers pose the questions.

The extract of T1's:

$O k$, the next question. Are the students

$\begin{array}{ll}T & \text { studying now? Are the students } \\ & \text { studying now? } \\ \text { SSS } & \text { Yes, they are. } \\ T & \text { Are the students studying outside? } \\ \text { SSS } & \text { No, they are not studying outside. }\end{array}$

The extract of T2's:

\begin{tabular}{|c|c|}
\hline$T$ & Gea! Is there any difficult word? \\
\hline$S$ & No. \\
\hline & Hey pay attention please. [hitting the \\
\hline$T$ & table] \\
\hline & Pay attention please.. Danu?! \\
\hline$S$ & Apa bu? \\
\hline$T$ & $\begin{array}{l}\text { How about you? What do you think, are } \\
\text { you interested? }\end{array}$ \\
\hline$S$ & No. \\
\hline$T$ & $\begin{array}{l}\text { Why? Why? What do you think about } \\
\text { this activity? Are you interested } \\
\text { practicing through song? You like this } \\
\text { song? }\end{array}$ \\
\hline$S$ & No. \\
\hline$T$ & $\begin{array}{l}\text { Kenapa? [walking approaching to } \\
\text { student's chair] (...) ya. You don't like } \\
\text { music? Music? }\end{array}$ \\
\hline$S$ & Like. Apa namanya. Music is my life. \\
\hline$T$ & $\begin{array}{l}\text { (...) about song? What kind of song? } \\
\text { What kind of song? }\end{array}$ \\
\hline$S$ & Reggae. Reggae. \\
\hline$T$ & $\begin{array}{l}\text { What kind of song? Febrian. How } \\
\text { about you? }\end{array}$ \\
\hline SSS & $\begin{array}{l}\text { Have you ever practice? } \\
\text { Dangdut dangdut bu. }\end{array}$ \\
\hline
\end{tabular}

The extract of T3's:

$T \quad$ Apa? What is it?

SSS Hand phone.

Hand phone. Do you know who created

$T \quad$ this? Do you know who invented this? [while showing her cell phone] tau siapa yang nemuin?

SSS Graham Bell. Alexander Graham Bell.

T Alexander Graham Bell. Tau dari mana?

SSS Daribuku bu. Internet.

Comparing to the Malaysian teacher, they posed the questions as follows:

The extract of T4's:

Alright. So, we are going to talk about dare to dream here and everyone is

$T \quad$ having dream right? what do you what do you have? Amira, what is your dream? (.)

S7 Aaaa... 
[interrupt] You better give one full

$T \quad$ sentence please. One full correct sentence Yes? What is your dream?

$S 7$

Hmmm .... to take to take my mom

The extract of T5's:

Okay literature (.) but I'm going start with the new/ aaa... topic today (.) so we have done our poem (.) dramas

$T$ and today we go on to/ short stories (.) a novel sorry (.) so "How I met myself" (.)

Okay I want to ask how many of you have read the story?

SSS (inaudible)

$T \quad$ Quiet number (.) how do you find?

SSS Interesting

T Interesting (.) why do you find

interesting?

SSS (inaudible)

T (laugh) Aishal

S1 Because it's mysterious

T Mysterious? Okay some more? Ha?

SSS Unique story

Okay so (.) we have done drama right when you were in form two (.) so now you look at how I met myself (.) okay

$T \quad$ those who have read the story (.) it's very interesting it's very mysterious (.) I want to ask you setting (.) about setting (.) okay you have read? Where does the story took place?

SSS Hungary

$T \quad$ Which part of Hungary?

SSS Budapest

The extract of T6's:

$T \quad$ What? What is it that? Do's and dont's/ SSS Yes

Okay the do's and dont's alright when

$T \quad$ visiting our country (.) it's about actually

the topic is about our local/

SSS Customs

Customs and/ traditions alright (.) what

$T \quad$ is custom? If you understand (.) what is

T custom? Who can give me definition what do you understand with the word custom?

$S \quad$ From the baby until old

$T \quad$ Sorry? From the baby until old/ is that custom?
SSS No
Okay anyone please give pssstttt... alright
$T \quad$ please give me example of our local custom? We have a lot of local customs
(.) name me one (.) yes Firdaus?
S2 Eat food right hand
$T \quad$ Yes again?
S2 Makan dengan tangan kanan

In addition, having lecture in the class allows the students to get background information or ideas, basic concepts, and methods required by them before they involve in the discussion session and engage in their own learning (Fry, et al., 2003). The role of the teacher is to make knowledge accessible to students, that is, to provide explanations. There are several ways this might be achieved, from teacher-led deductive explanations to guiding the students through a process of inductive discovery (Tsui, 1995; Farahian \& Rezaee, 2012). In explanations, all teachers deliver material clearly. The extract of T1's shows that she gave explanation to the students about yesno questions (linea 132-143). Then, the extract of T3's shows the teacher gave explanation about International Drive Dialing (IDD). The extracts are as follows:

The extract of T1's:

They are right, ok. Now, let we (..) the next ee (.) 2 pages, the next two pages.

$T \quad$ Now, do you know what is grammar? [the teacher takes her hand out and shows to the students].

S Tata bahasa. [structure] [the students looks at their hand out].

Tata bahasa, or it means "struktur" $T \quad y a$. Ok, yes no question ya. Yes no question are the simplest type. Do you know "type?" [looks at the hand out]

SSS Tipe.

Tipe yang simpel, yang paling simpel dari pertanyaan. <the simplest type of question>. Yes no question adalah the

T: $\quad$ simplest type of question atau pertanyaan yang paling sederhana. They can simply be answered by "yes or no" atau "ya atau tidak'. Nah, the 
example, let's see the example. Everybody please repeat after me ya. [the students and the teacher read a text on the hand out].

Are you a doctor?

\section{The extract of T2's:}

There are so many similar sounds, there are so many repeated words. Ya. You can learn from this kind of song. Ya kan? (.) belajar bahasa Inggris itu dengan lagu.

$T \quad$ Banyak kan di situ, similar sound. What is similar sound? What does it means similar sounds?

Susan shall sell some small shoes in the

$T$ shoes shop. [the teacher writing the answer in the whiteboard]

SSS Panjang amat bu?

How many words have you (.) ya. This is

$T$ the example of similar sound ya. There are how many similar sounds? [pointing out one of the students]

The extract of T3's:

Sambungan Langsung International. Ok. International Drive Dialing. Kalo kalian nelfon, tiba-tiba ada nomer $62+$ ada nomer $62+[$ illustrating using her finger] that is an Indonesian country code. Kode Negara

$T \quad$ Indonesia,(.) if you have family outside and they will call you in Indonesia, they have to push two number an Indonesian code. Jadi kalo di buku dari Telkom ya yellow pages, buku dari Telkom yang dibagiin beberapa nomor. Belum pernah liat?

The extract of T4's:

Correct. Good. Here, simple present.

$T \quad$ The annual book festival will be held on 27 April 2013 at PWTC. Correct or wrong?

SSS Wrong

$T \quad$ Correct or wrong?

SSS Wrong wrong

$T \quad$ Why is it wrong?

SSS Will will

$T \quad$ Because of will be. You are talking about simple present. First, sentence is correct. But we are talking about simple present tense. So, simple present tense does not havel

SSS Will be

$T \quad$ Will be is used for what

SSS Future tense

Yes, future tense. Okay we are talking about future tense. So, this one is wrong. The sentence is correct. Okay.

$T$ The grammar is correct. Min Hwa is having his dinner [students laugh] okay, simple present tense/simple present tense/ is this a simple present tense?

The extract of T5's:

Not not really (.) okay so on the characters on your left side page four

$T \quad$ roman you have the characters there (.) ah you Have John Taylor (.) English computer programmer -

Okay working for a multinational T company in Budapest (.) and then you have Andrea Taylor

SSS John's wife John's wife (.) teacher of Hungarian (.)

$T \quad$ and we have () you know how to read ( )

SSS K- $a$ - $t i$

Yes Kati k-a-t-i in Malay k-a-t-i in Malay spelling the pronunciation yes

$T \quad$ ka/ti (.) okay Kati Taylor (.) John and Adrea's baby daughter aaa...how do you pronounce that Zsolt?

The extract of T6's:

$S \quad$ Teacher deserted?

Deserted means lonely (.) from the word dessert not desert (.) desert

$T \quad$ desert sorry from the word desert not dessert (.) okay

$S \quad$ (Freeband)

(Freeband) means that we try aaa ...we don't want things that those things to

$T \quad$ happen (.) alright? Okay? Let see you drink less water what will happen? What will happen to your body?

$S \quad$ Dehydration 


\begin{tabular}{|c|c|}
\hline$T$ & $\begin{array}{l}\text { Dehydration (.) so we need to drink a } \\
\text { lot of water to prevent/ }\end{array}$ \\
\hline$T$ & $\begin{array}{l}\text { Malaysia is a country (.) Malaysia is a } \\
\text { hot country (.) yes part of the sentence } \\
\text { (.) but I tell you that you have to find } \\
\text { the action verb first (.) so what is the } \\
\text { action verb there? Is Malaysia an } \\
\text { action verb? }\end{array}$ \\
\hline$S S S$ & $\begin{array}{l}\text { No } \\
\text { No Malaysia is not an action verb }\end{array}$ \\
\hline$T$ & $\begin{array}{l}\text { the word clothes (.) is it the word cloth } \\
\text { an action verb? Clothes is a noun }\end{array}$ \\
\hline$S S S$ & $\begin{array}{l}\text { Wear } \\
\text { Wear yes yes wear is an action verb (.) }\end{array}$ \\
\hline$T$ & $\begin{array}{l}\text { so you have to start with the word wear } \\
\text { (.) }\end{array}$ \\
\hline
\end{tabular}

In using L1, three teachers from Indonesia took higher than three teachers from Malaysia. From the extracts between T1 and $\mathrm{T} 4$, it can be seen clearly that Indonesian teachers produced many words in L1. For Malaysian teachers, they only produced and uttered L1 only some words during teaching process.

The extract of $\mathrm{T} 1$ :

The answer of the question, yes, or no. Jawabannya hanya ya atau Tidak.

$T \quad O k$, yes no question hanya dijawab ya atau tidak. Ok, (..) ya. For example, ee (.) are we in the class?

The extract of T2's:

What have you see Catur? Hey Catur! Halo halo halo! Ribut terus dari tadi

$T$ kenapa sih?! Raise your hand if you don't understand. Nah suruh tunjuk tangan juga masih gak ngerti tapi masih banyak tanya.

S Sayabu.

T Danu.

$S \quad Y a$,

Pay attention to your card, and then

$T \quad$ listen to the lyric. If your card lyric is the same with this, what have you search, put it, put your card on the floor.

$S \quad$ On the floor?

T Ya. Paham?
S Yes, paham.

$T \quad Y e s, y a$. Who still don't understand?

$S \quad$ (.) bu?

The extract of T3's:

Pioneer? You know pioneer? Pioneer? Pioneer is pemula. Pemula. For example

$T \quad$ you are a pioneer of new style. Misalnya kamu pemula untuk model rambut baru ya. Kamu create sendiri, terus mereka pada mengikuti kamu. That is pioneer.

$S \quad$ Pioneer.

For example gini eeeem long time ago $y a$, Sidomulyo is still a jungle and then the government has transmigration program, some people from outside move to Sidomulyo and cut the jungle, [waving hand seems cutting a trees] and they first

$T$ to be the settler in Sidomulyo, so they start living in Sidomulyo, and years people come to Sidomulyo [waving her hand in telling the story] and now (.). So, the first people who settle in Sidomulyo is called as pioneer. Pemula. Pengawal suatu usaha ya, ok?

S Ya.

So, Lampung is the center of transmigration program in the Dutch colony time. Sejak jaman Belanda dulu, Lampung jadi target untuk transmigration program. Lampung is only three, one of them is Sidomulyo and

$T$ then Pringsewu. So, they become the pioneer of people now in Sidomulyo and Pringsewu and the other part of Lampung province. Ok got it? That is the meaning of pioneer. Mana lagi yang gak tau?

S Throughout.

Throughout. [writing on the whiteboard] Throughout itu menyeluruh diseluruh.

$T \quad$ Throughout the world seluruh dunia. [waving the hands make a circle] Who don't know Barrack Obama.

The extract of T4's:

$T$ .... Okay, this group siapa yang volunteernye? Nurhayati. Okay come. One sentence here please. 
That group. Now Seth come here please.......

The extract of T5's:

$\begin{array}{ll}T & \text { Liyana? Zudin please wear your (.) } \\ S & \text { samping yes } \\ T & \text { Cik gu tak dapat cik gu } \\ \text { SSS } & \text { Why? } \\ & \text { Tak dapat } \\ & \text { Oh tak dapat (.) okay any extras? } \\ & \text { Pass pass now (.) okay you look at } \\ & \text { summary chapter one a strange } \\ T & \text { meeting (.) this is the summary of } \\ & \text { that ya (.) okay someone please } \\ & \text { read? A strange (.) summary (.) can } \\ & \text { you see that? }\end{array}$

The extract of T6's:

Alright (.) obviously during hari

$T \quad$ raya (.) how about the Indians?

What do you wear to show your traditions?

SSS Sari sari

Sorry? For examples the Malays they wear our traditional clothes $T$ such as baju Melayu and baju kurung (.) how about the Indians? What do you wear (Shargis)?

\section{Classroom Discourse}

The second finding from this research is the classroom discourse. After observing the lessons, it is discovered that Indonesian teachers employed four types of interaction characteristics - dialogue, use of L1/L2 for both teachers and students, accepting incomplete answers from students, and accepting one word answers. On the other side, the Malaysian teachers used seven types of interaction characteristics which include monologue, dialogue, restructure discourse, fill gaps for students lack of language, use of L1/L2 (for both teacher and students), accepting incomplete answers from students, and accepting one word answers.

The difference of Indonesian and Malaysian teacher was clearly seen in using L1/L2 during the lesson. The portion of
Indonesian teachers and their students in using mother tongue was higher than Malaysian teachers and students. The following extract shows how Indonesian teachers and their students used L1/L2 during teaching process: The extract of T1's:

$T \quad Y o u$ know it. Ok, Are you a doctor?

SSS Apakah kamu seorang dokter.

T Yes I am.

SSS Iya.

$T \quad$ Are you a student too?

SSS Apakah kamu seorang pelajar juga?

T Yes I am.

SSS Ya.

T Are you a student too?

SSS Apakah anda seorang pelajar juga? No, (..)

T Dia adalah seorang

SSS (..)

The extract of T2's:

$T \quad$ Paham apa tidak?

$S \quad$ Iya paham

What have you see Catur? Hey Catur!

Halo halo halo! Ribut terus dari tadi

$T \quad$ kenapa sih?! Raise your hand if you don't understand. Nah suruh tunjuk tangan juga masih gak ngerti tapi masih banyak Tanya.

S Sayabu.

The extract of T3's:

$T \quad$ Sudah mengerti isinya?

S Belum.

Ok now, maybe you have difficult

T vocabulary. Ada kata-kata yang sulit gak? Ya?

SSS Ada.

\section{CONCLUSION}

The study discovered that all classroom practices reflect the teachers' characterictics in shaping classroom interaction (Richards \& Rodgers, 2001; Mustapha, et al, 2010). All teachers performed two characteristics of classroom interaction namely teachers language accuracy and classroom discourse. In teachers language accuracy, the Indonesian and Malaysian teachers delivered 
pronunciation, vocabulary, instructions, questions (Graesser, Gernsbacher, \& Goldman, 2003; Hall, 2011), explanations, eliciting information, use of L1, and correction of language errors (Hall, 2011). They also applied monologue, dialogue, restructure discourse, fill gaps for students lack of language, use of L1/L2 both teachers and students, accepting incomplete answers from students, and accepting one word answers.

Different belief systems among teachers can often explain why teachers conduct their classes in different ways. The teachers, also, are required to be a skillfull manipulator using questions, commands, and other cues to elicit correct sentences from the students. Thus, lessons are hence teacher-directed and the teachers set the pace (Richards \& Rodgers, 2001).

Identifying the characteristics of classroom interaction is beneficial to the teachers in managing their classrooms. With this understanding, the teachers might plan strategies and apply suitable teaching techniques to build a responsive classroom. Thus, it is paramount for the teachers to create a condusive classroom environment so that it may stimulate the students' active involvement during teaching-learning process.

\section{REFERENCES}

Angrosino, Michael \& Rosenberg, Judith. (2013). Observations on observation, continues and challenges. In Denzin, Norman $\mathrm{K}$ and Lincoln, Yvonna $\mathrm{S}$ (Eds.). Collecting and Interpreting Qualitative Materials (pp. 151-176). Los Angeles: Sage Publications.

Brown, H. D. (2000). Principles of Language Teaching and Learning (The 4th Edition). White Plains, New York: Longman.

Dagarin, M. (2004). Classroom Interaction and Communicate Strategies in Learning English as a Foreign. Ljubljana: Birografika Bori.
Di Grapello, Emanuela. (2013). Role of education and training sector in addressing skill mismatch in Indonesia. In Suryadharma, Daniel \& Jones, Gavin. $\mathrm{W}$ (Eds.). Education in Indonesia (pp. 236-266). Singapore: Institute of Southeast Asian Studies.

Farahian, Majid \& Rezaee, Mehrdad. (2012). A Case Study of an EFL Teacher's Type of Questions: An Investigation into Classroom Interaction. Procedia Social and Behavioral Sciences, 47, 161-167.

Fisher, D. \& Frey, N. (2007). Checking for Understanding (Formative Assessment Techniques of Your Classroom). Alexandria: ASDC Publications.

Fry, H., Ketteridge, S., \& Marshall, S. (2003). A Handbook for Teaching and Learning in Higher Education (Second Edition). London: British Libabry Cataloging.

Graesser, A. C., Gernsbacher, M. A., \& Goldman, S. R. (2003). Handbook of Discourse Processes. New Jersey: Lawrence Erlbaum Associates, Inc., Publisher.

Hall, Graham. (2011). Exploring English Language Teaching: Language in Action. New York: Routledge.

Hall, J. K. \& Walsh, M. (2002). TeacherStudent Interaction and Language Learning. Annual Review of Applied Linguistics, 22, 186-203.

Howard, Amanda. 2010. Is there such a thing as a typical language lesson?. Classroom Discourse, 1 (1): 82-100.

Ibrahim, Noraini., Haniem, Azliza., \& Nambiar, M.K. Radha. (2013). What master teachers do: A case study of planning, facilitating, role modeling, and developing materials. International Education Studies, 6 (6): 86-94.

Jones, L. (2007). The Student-Centered Classroom. Cambridge: Cambridge University Press.

Kuijpers, J.M., Houtveen, A.A.M., \& Wubbels, T. (2010). An integrated 
professional development model for effective teaching. Teaching and Teacher Education, 26: 1687-1694.

Li, Winnie Sim Siew \& Arshad, Mohammad Yusof. (2015). Inquiry pactices in Malaysian secondary classroom and model of Inquiry teaching based on verbal interaction. Malaysian Journal of Learning and Instruction, 12, 151-175.

Lie, Anita. (2007). Education policy and EFL curriculum in Indonesia: between the commitment to competence and the quest for high scores. TEFLIN Journal, 18 (1): $1-4$.

Lomax, H. T. \& Ferguson, G. (2002). Language in Language Teacher Education. Amsterdam: John Benjamins Publishing Company.

McCormick, D. E \& Donato, R. (2000). Teacher Questions as Scaffolded Assistance in an ESL Classroom. In J. K. Hall \& L. S Verplatse (Eds.), The Development of Second and Foreign Language Learning through Classroom Interactio. LEA.

Marcellino, M. (2008). English language teaching in Indonesia: a continuous challenge in education and cultural diversity. TEFLIN Journal, 19 (1): $57-$ 69.

Mattarima, Karim \& Hamdan, A.R. (2011). The teaching constraints of English as a foreign language in Indonesia: the context of school based curriculum. Sosiohumanika, 4 (2): 287-300.

Mustapha, S. M., Rahman, N. S. N. A., Yunus, M. Md. (2010). Perceptions towards Classroom Participation: A Case Study of Malaysian Undergraduate Students. Procedia - Social and Behavioral Sciences, 7 (C), 113-121.

Noor, Noorizah Mohd., Aman, Idris., Mustaffaa, Rosniah., \& Seong, Teo Kok. (2010). Teacher's verbal feedback on students' response: a Malaysian ESL classroom discourse analysis. Proceedia
Social and Behavioral Sciences, 7 (C): 398-405.

Richards, J. C. \& Farrell, T. S. C. (2005). Professional Development for Language Teachers: Strategies for Teacher Learning. New York: Cambridge University Press.

Richards, J. C. \& Rodgers, T. S. (2001). Approaches and Methods in Language Teaching. USA: Cambridge University Press.

Richards, J. C. \& Schmidt R. (2010). Longman Dictionary of Language Teaching and Applied Linguistics, 4rd edition. London: Longman.

Rido, Akhyar. (2018). Profiling English languae teachers in Indonesian and profiling their classroom dynamics. Proceedings of the Seventh SRS Teflin National Conference (pp. 11-20).

Rido, Akhyar. (2017). What do you see here from this picture?: Questioning strategies of master teachers in Indonesian vocational English classrooms. TEFLIN Journal, 28 (2): 193-211.

Rido, Akhyar., Afrianto., Sari, Fatimah Mulya., Suri, Ria Augie., \& Duantoro, Hadi. (2017). Discourse Structure of Lecture in L2 in the Indonesian Tertiary Context. Proceedings of the Fifth International Conference on English Language and Teaching (pp. 11-20).

Rido, Akhyar., Ibrahim, Noraini., \& Nambiar, M.K. Radha. (2016). Teaching and classroom management strategies of Indonesian master teachers: Investigating a vocational English classroom. 3L: The Southeast Asian Journal of English Language Studies, 22 (3): 93-109.

Rido, Akhyar., Ibrahim, Noraini., \& Nambiar, M.K. Radha. (2015). Interaction strategies of master teachers in Indonesian vocational classroom: A case study. 3L: The Southeast Asian Journal of English Language Studies, 21 (3): 85-98. Rido, Akhyar., Ibrahim, Noraini., \& Nambiar, 
M.K. Radha. (2014). Investigating EFL master Teacher's Classroom Interaction Strategies: A Case Study in Indonesian Secondary Vocational School. Proceedia Social and Behavioral Sciences, 118: 420-424.

Rido, Akhyar. (2010). The use of discourse markers as an interactive feature in science lecture discourse in L2 setting. TEFLIN Journal, 21 (1): 90-106.

Suharti. (2013). Trends in education in Indonesia. In Suryadharma, Daniel \& Jones, Gavin. W. Education in Indonesia (pp. 15-52). Singapore: Institute of Southeast Asian Studies.

Tsui, A. (1995) Introducing Classroom Interaction. London: Penguin.

Tsui, A. B. M. (2001). Classroom Interaction (Chapter 17). In Carter, R. \& Nunan, D. (2001). The Cambridge Guide to
Teaching English to Speakers of Other Languages. Cambridge: Cambridge University Press.

Tuan, L. T. \& Nhu. (2010). Theoretical Review on Oral Interaction in EFL Classrooms. Studies in Literature and Language, 1(4), 29-48.

Walsh, Steve. (2011). Exploring Classroom Discourse: Language in Action. New York: Routledge.

Wong, Jean \& Waring, Hansun Zhang. (2010). Conversation Analysis and Aecond Language Pedagogy. New York: Routledge.

Zulfikar, Teuku. (2009). The making of Indonesian education: an overview on empowering Indonesian teachers. Journal of Indonesian Social Sciences and Humanities, 2: 13-39. 